\title{
MEASURING THE CUSTOMER SATISFACTION OF ECONOMIC CAPITALIS THEORY
}

\author{
SUMADI \\ STIE - AAS Surakarta \\ Email:sumadi@stie-aas.ac.id
}

\begin{abstract}
Profits earned by employers and wages earned workers essence is the price. The profit for the entrepreneur is the price he gets from the consumer, while the wage for the worker is the price that the employer must pay. Thus price is the driving force of production. From the above explanation, it can be deduced that the productive or productive activities of man in the view of Capitalism is a human sacrifice driven by material incentives. Consumer Behavior Theory studies how humans choose between the various options they face by utilizing the resources it has. The theory of rational consumer behavior in the conventional economic paradigm is based on the basic principles of utilitarianism. Initiated by Bentham who says that in general no one can know what is good for his own good except the person himself. Thus restrictions on individual freedom, either by other individuals or by the authorities, are evil and there must be a compelling reason to do so. Profits earned by employers and wages earned workers essence is the price. The profit for the entrepreneur is the price he gets from the consumer, while the wage for the worker is the price that the employer must pay. Thus price is the driving force of production. From the above explanation, it can be deduced that the productive or productive activities of man in the view of Capitalism is a human sacrifice driven by material incentives.
\end{abstract}

Keywords: Cost of Production, Selling Price

\section{Introduction}

Humans have different kinds of needs, both physical and spiritual. In the definition of economics, consumption is an activity that aims to reduce or spend the usefulness of an object (goods and services) in order to meet the needs. How a consumer meets his needs with his own income as taught in economics. The definition of Economics is a science that studies the way humans in utilizing, managing, and using existing natural resources to meet their needs and desires. One of the economic activities discussed in economics is the behavior of consumers in meeting their needs. In the view of conventional economic theory, the

behavior / behavior of consumers is based on the rule of absolute freedom.

Consumer behavior theory can be distinguished into to two kinds of 
approaches: the cardinal use approach (utility) and the ordinal value approach. In the approach of cardinal use value is considered the benefit or enjoyment obtained by a consumer that can be expressed quantitatively. Based on this consideration, and assuming that the consumer will maximize the satisfaction it achieves, it explains how one will determine its consumption over the various items on the market. In the ordinal value approach, the benefit or enjoyment the community derives from assuming the goods are not quantified. The behavior of a consumer to choose the goods that will maximize his satisfaction is shown by the help of the same satisfaction curve, i.e. the curve that describes the combination of goods that will give the same value (satisfaction) (Sadono Sukirno, 2004). Consumer Behavior Theory (consumer behavior) studies how humans choose between the various options they face by utilizing the resources it has. The theory of rational consumer behavior in the conventional economic paradigm is based on the basic principles of utilitarianism. Initiated by Bentham who says that in general no one can know what is good for his own good except himself. Thus the restrictions on individual freedom, either by other individuals or by the authorities, are evil and there must be a compelling reason to do so.

The scarcity of economic resources in the first economic lesson facing a student at school or the first discussion of introductory microeconomics courses at the Faculty of Economics is a discussion of infinite human needs and limited economic resources. In the literature it is also mentioned in the first chapter section on the definition of economics, that is how to meet unlimited human needs while the goods available to meet these needs are limited.

This is the economic problem that became the foothold in the Capitalist Economic System as well as the philosophy of his life. There has been no difference in the views among capitalist economists since the time of Adam Smith up to the present day concerning the problem of scarcity faced by unlimited human needs.

\section{Literature Review}

\section{a Consumer Behavior Theory in Conventional Economics}

Consumer behavior theory is the the theory which studies how humans choose among the various options they face by utilizing the resources it has. The theory of rational consumer behavior in the conventional economic paradigm is based on the basic principles of utilitarianism. Initiated by Bentham who says that in general no one can know what is good for his own good except the person himself. Thus restrictions on individual freedoms, either by other individuals or by the authorities, are a crime and there must be a compelling reason to do so (Karim, A. Ir., 2007).

Based on the problems that became the foothold in the Capitalist Economic System, then the capitalist economic experts see there are 3 economic issues that must be solved the community, namely:

1. What to produce and in what quantity (What)?

2. How are the economic resources (factors of production) available to be used for producing the goods (How)? And,

3. For whom the goods are produced; or how are these items distributed among the citizens (for Whom)? (see Boediono: 1993: 7) 
Discussion of the first question, namely "what to produce" ?? in general concerning goods and services needed by human beings, and in particular concerning the synchronization between human needs and purchasing power. While the discussion "how many goods produced" ?? is the discussion that became the answer of the level of demand of consumers total (aggregate) which are determined by what goods he needs and to what extent the purchasing ability.

The second question, namely "how to use economic resources in producing goods and services needed?" concerning the discussion of production techniques. It's just that the economic experts of capitalism do not separate the discussion of this issue with other economic problems.

Finally, about the question "for whom the goods are produced?" the capitalist economists answer it with a discussion of the price theory, namely the role of prices in determining production - consumption distribution.

\section{b The Solution of Capitalism on Scarcity Problem}

Back to the problem of scarcity. The answer to the problem of the clash between unlimited human needs and the limited (scarcity) of available economic resources is by increasing the maximum amount of goods and services so that unlimited human needs can be reduced. Although the answer to the problem ultimately has to collide with the level of consumer demand, where the level of consumer demand is influenced by many factors, so the level of production in real terms is not as much production as it can lead to inefficiency and market disequilibrium, but philosophy problem solving (problem solving) economy in this way determines how the Capitalist Economic System sees the essence of economic problems. With this viewpoint, then for the Capitalist Economic System, the economic solution that must be pursued micro is the increase in production as much as possible, and macro pursues the highest economic growth.

\section{Micro Solution}

The micro-solution as previously discussed will clash with the demand level, so if it continues in the real economy when it reaches the stage of market imbalances, it will lead to such an unfavorable (uneconomic) economic solution. This problem is very much appreciated by the capitalist economists themselves, especially at the level of practitioners (entrepreneurs), so that real production is done with attention to the level of demand.

\section{Macro Solution}

The macro solution that is the highest economic growth is an economic target that must be pursued and is absolute. It's just that the capitalist economic experts and economic policy holders must be realistic in determining how the target of economic growth if viewed the economic situation of the potential and problems that is faced by a country. Although it must be realistic to set economic growth targets, every country that embraces the capitalist economy (both capitalist and capitalist countries) still makes economic growth a target that must be pursued both in the economic boom (high economic growth), recession (low economic growth and stagnant tendency), as well as in a state of depression (minus growth in a few years). 
Economic growth is also be the main benchmark (economic indicator) of economic achievements of developed countries and economic development achievements of developing countries. On the other side, various macroeconomic indicators are placed in two positions, which are designing several macroeconomic indicators (such as investment rates, interest rates, local currency exchange rates, consumption and production) as locomotives or drivers of economic growth, and making other macroeconomic indicators (such as unemployment, poverty) depends on the rate of economic growth.

Consequently, in order to achieve the targeted economic growth rate (especially the high economic growth target), the aggregate domestic production of aggregate goods and services must be boosted by increasing investment in both domestic and foreign investment. Increasing domestic investment is pursued through the expansion of bank credit to entrepreneurs by lowering interest rates, increasing government spending financed from domestic sources and foreign loans. Increasing foreign investment is pursued by opening foreign investment taps, trade liberalization, financial liberalization, and liberalization of various local businesses for the benefit of investors.

Achieving high production in aggregate should be followed by an increase in public consumption. So for that the producers create an engineering through means of advertising and various other efforts so that in the community formed consumptive lifestyle. In addition, banks are also encouraged to provide more consumer loans with lower interest rates.
Thus, making economic growth a major economic problem, requires a country to liberalize its economy for the benefit of domestic investors and foreign investors so that every economic policy of the country should be a pro market policy. As for the market here is the economic transactions conducted by economic actors both government, employers, and society. But the most dominant market player in the Capitalist economy is a competing entrepreneur or producer, meaning capitalist owners. So the pro-market government policy is pro-capitalist (capitalist) policy, and now they are commonly referred to by the more refined terms of the investor.

Making the production of goods and services as high as an economic solution in the Capitalist Economic System proves that for Capitalism economic problems do not lie in how to meet human needs, but are concentrated on how to produce goods and services. That is, the attention of this system in solving economic problems is the substance that becomes the human need, not the human itself or in other words whether the needs of an individual that has been fulfilled or not yet become the problem of Capitalist Economic System, it is the problem is the production of roads not? or how much production capacity can be done.

\section{c Outlook About Goods Value}

Discussion about value in capitalism is something very urgent. Because the values used to see goods and services, also to determine the ability of producers and consumers. There are two categories of discussion about the value of goods and services, namely the discussion that discusses the value of the usefulness of goods for the individual which is then referred to as the utility value, and the 
discussion associated with the value for goods related to other goods called exchange rates.

Adam Smith distinguishes between value of use and the value in exchange. But the socalled paradox (contradiction in principle), which allows the goods that the level of use such as air and air, but the exchange rate is different even may not have a price at all. David Ricardo added that the usefulness of goods is a requirement for the entry into force of the exchange rate. But the Capitalist Economy System in this classical school cannot solve the above paradoxical problem (Zimmerman: t.t: 39-40).

\section{d Utility Value According to Capitalism}

The first category of discussion called utility value in Capitalism is represented by the view of boundary satisfaction theory or the marginal satisfaction theory. While the definition of marginal satisfaction theory or marginal utility (MU) is the satisfaction or usability value obtained by a person (consumer) from consuming the last unit of the goods consumed (Reksoprayitno: 2000: 147). Nabhani also mentions that the use value is the unit of one item measured by the last usefulness of the object, or the use of the unit used to meet the lowest needs (An Nabhani: 2000: 9). The value of use in Capitalism outlook is also called "subjective value" because it is very subjective for every individual.

In the measurement of use values, it is assumed that the level of one's satisfaction can be measured. While the unit of measure to measure one's satisfaction is called util (unit of satisfaction) (Ibid: 146). It is also assumed (although this is not realistic) that the total satisfaction of consuming two or more items can be obtained by summing the unit of satisfaction obtained from each consumed item (the additive assumption) (ibid). For example, for Faqih (according to its subjectivity) a pack of yellow rice yields a satisfaction of 10 utils and 1 cup of hot tea yields 3 utils, resulting in total satisfaction of 13 utils.

The next assumption is that the more units an individual consumes, the smaller the limit the person gets, and eventually becomes negative. This theory is known as "the law to limit the decline"?? (the law of diminishing marginal utility) also known as "law gossen I", since this view was first put forward by Hermann Heirich Gossen (18101858 AD) (ibid: 147) to answer the deadlock of classical school theories about the paradox of value against exchange rate.

An example of this theory is that when Faqih consumes 1 pack of yellow rice, then for Faqih the uses value of yellow rice is for example 10 utils. Since Faqih is still hungry, he adds another pack of yellow rice, and for him the value of one second yellow rice is fixed 10. Faqih is feeling full, but the money in his pocket is at least still enough to buy two packets of yellow rice, therefore Faqih decided to buy another packet with the consideration of too little money left not to spend the rest of his money. Because it is satisfied so that a third yellow rice packet is not required Faqih but he wants it, then Faqih assume the use value of one yellow rice has dropped to 5 util.

Faqih willing to pay his groceries to the aunt of yellow rice seller, the aunt persuaded Faqih to buy the remaining one yellow pack of yellow rice. But Faqih did not fulfill the request. Aunty yellow rice seller persuaded again by lowering the price of one pack of yellow rice remaining to 
$25 \%$ of the original price, but Faqih still refused. Why did not Faqih want to buy a fourth yellow rice packet even though the price fell drastically? The answer is that for Faqih a fourth yellow rice pack is no longer useful to him, because he is so full that he does not need food. This means that at the time, for Faqih the value of one pack of yellow rice the fourth is 0 util.

Even if Faqih is willing to fulfill the request of the aunt and eat it at that moment, then the stomach will be overcrowded so that the stomach ache and the rice cannot be spent, so in such condition the use value of a fourth yellow rice pack reaches a negative point, and perhaps Faqih consider it value point to -10 utils.

\begin{tabular}{|l|l|l|}
\hline $\begin{array}{c}\text { Wrap the } \\
\text { Yellow Rice } \\
\text { That is to } \\
(\mathrm{n})-\end{array}$ & $\begin{array}{c}\text { Use Limits / } \\
\text { Marginal } \\
\text { Utility }\left(\mathrm{MU}_{\mathrm{n}}\right)\end{array}$ & $\begin{array}{c}\text { Total Use } \\
\text { Total } \\
\text { Utility } \\
\left(\mathrm{TU}_{\mathrm{n}}\right)\end{array}$ \\
\hline 1 & 10 & 10 \\
2 & 10 & 20 \\
3 & 5 & 25 \\
4 & -10 & 15 \\
\hline
\end{tabular}

From the example above, it can be explained that what is meant by the marginal utility for Faqih is when he reaches the maximum total satisfaction level by eating another pack of yellow rice, for at the time of eating a pack of yellow rice the third is he get the last added satisfaction of 5 utils so that for him the value of satisfaction that he can get by 25 utils. If he buys a fourth yellow rice packet, it does not add anything to him, and if one packs the fourth yellow rice he eats, his total use value is reduced to 15 utils. So according to this theory, maximum satisfaction for Faqih is when Faqih consume yellow rice as much as 3 packs.
Based on the explanation above, it is clear that the intended use value of goods and services in capitalism is determined by the individual subjective judgment of one unit or several units of goods consumed at the time of achieving maximum satisfaction. Thus, based on "the law of limits which is declining", at a certain point the value of the use of a good decreases, at a certain point also an item is not considered useful to the individual, and even at the negative point the item is considered utterly useless. Well In this view, then an individual is required to consume goods as much (greedy) to the limit of maximum satisfaction not to the limit as needed.

\section{e Exchange Value According to Capitalism}

The exchange value is defined as the exchange value of an item with other goods or the value of an item as measured by other goods (An Nabhani: 10: 2000). For example in a society, the value of a goat is equivalent to 50 chickens, or another example of a pack of yellow rice priced at 4 cups of hot tea. In order to achieve a perfect exchange mechanism or to avoid the difficulty of assessing the exchange rate of an item against other goods, there must be a medium of exchange which is the measure of all goods and services (ibid). Money is a means of exchange that facilitates transactions. The meeting between money and goods valued with a sum of money is called price. So price is a special term exchange rate of a good. Or it can be said the difference between the exchange rate with the price is the exchange rate is the absorption of the exchange of goods with other goods absolutely, while the price is ratio exchange rate of goods with money. 
The discussion of the second category of the value of this item in Capitalism places the price as a special term of exchange rate in a very important discussion.

\section{f Price Structure}

Broadly, the price level of goods and services is determined by the strength of demand and supply power. When the price is seen from the price itself which then affects the level of demand and supply, then it can be illustrated as follows: when the price rises producers increase the amount of production and consumers lower their consumption. Conversely, when the price drops producers reduce production and increase consumer consumption. The logic of this theory does not occur absolutely and necessitates the conditions (assumptions) for the theory to occur, as other factors are considered fixed (cateris paribus). In real terms the theory is not necessarily the case, because there are several types of goods and services that when the price rises consumers do not reduce consumption as long as he is still able to pay, such as rice. Nor does the producer necessarily increase production when the price of the goods it produces rises, because of the likelihood of losses it will incur if increasing the production rate, and vice versa.

When the price is seen from the strength of demand and supply affecting the price, it can be illustrated as follows: when supply rises due to overproduction and on the other hand consumer demand does not rise (or decreases), a new equilibrium with declining price levels. When supply falls due to lower production levels while demand does not change (or increase), then the price will increase. Then the power of demand and the strength of each offer is influenced by internal capacity factors that are also measured by price. In the bid power, where the supply level is based on the maximum amount of production that the producer can make or the amount of production the producer wants is determined by how much the production cost should be borne by the producer and the capability of the producer himself in paying the production cost. Thus the production cost or the price of production which includes the cost of capital, raw materials, wages, rent, taxes, interest, etc., are the main factors determining the producer's production capability.

The strength of consumer demand is determined by the usefulness of the goods and services offered to consumers, the consumers' need for the goods and services, and their ability to buy or consumer purchasing power. From these three factors, the consumer's purchasing power factor ultimately determines the power of demand. That is, when an item on the market is considered to have a usefulness for consumers, then he was interested or want the goods. However, this factor has not been too strong to create consumer demand. Furthermore, the need factor (let alone the urgent need) of the consumer of the goods gives a strong impetus for the consumer to own and consume it, so this factor gives a strong impetus to the consumer in the request. However, this second factor is not absolute, because there are people who decide to buy a product not because of the needs, but simply want to own and consume the goods, especially in a society that has a consumptive lifestyle, the decision to buy is not because of needs.

It's just that until this second stage of the factor, the impulse has not been realized 
so that the real demand in the market has not yet been established. To make it happen then the consumer must buy the goods he needs or unless there is a generous party who gives the goods he asked for free. So the decision to buy or not depends heavily on the purchasing power of consumers, where purchasing power is determined by the income of consumers and property owned. So the power of purchasing power that is also measured by price is the final factor that determines consumer demand.

\section{g Price and Its Role in Economy}

There are at least two functions of price in the Capitalist Economy System, namely as a standard value of goods and its role in determining the activities of production consumption - distribution.

Price as Standard Value of Goods

In the previous discussion mentioned that the use value of a good is the end of the consumption of goods that still provide usefulness for the individual, so for the individual at a certain point of a useful value, then the value of the use decreases with the decreasing of the level of satisfaction he gets from consuming the goods, and the item is deemed useless (its limit value $=0$ ) for the individual when the item is not satisfactory, and at a certain point the value of a good is considered negative for him because if he consumes it he gets no additional satisfaction but otherwise lowers the level the total satisfaction it gained.

So in price discussions as the standard value of goods, the price determines what goods have utility and what goods do not have a disutility, also the price determines how high the usefulness of a good (An Nabhani: 2000: 11).
For society, a good or service that is considered to have a usefulness by giving a certain measure that the goods have a price. While the level of usefulness is measured by the level of price received by the community for the goods and services concerned that the producers have offered. And vice versa, a good is not considered useful when society does not give price to the goods.

\section{$h$ The Role of Price in Capitalist Economic Activity}

For the Capitalist Economic System, prices have a role in production, consumption and distribution through the pricing structure.

Within the scope of production, the price determines who the producers are allowed to enter into the production area and anyone who cannot enter or leave the production area (ibid: 12). The price structure by itself will regulate and screen producers based on the level of the producer's ability to cover production costs which include the cost of procurement of capital goods, building and land costs, raw material costs, labor and management costs, maintenance costs, interest costs, tax costs, other.

Then the price structure will also filter out the producers who remain in the production area, when the burden of production costs can still be borne by the producer which may be caused by the existing stock of capital owned by the manufacturer, or because of the producer's innovation ability in managing efficient management and production quality meet market tastes, or because the producer practices unfair practices by destroying market prices, monopolies, or other 
fraudulent practices that rival producers are thrown from the production area.

The mechanism of economic competition like this by making the price as a tool that controls the producers in the production area, then the ownership of production in the Capitalist Economic System is determined by the power of capital owned by the producers, so that the weak people who do not have the capital capability will be thrown from the production area and eventually become the community marginal society.

\section{i The Role of Price in Determining Consumption}

In the scope of consumers, price is a controlling tool that determines the ability of consumers to meet various needs and desires. Price is a mechanism that excludes the poor and the needy from the economy because of their inability to reach the price level. Price is a mechanism that allows people to be able to buy the wealth they want with the money they have.

The price also makes people's lives mediocre. The crude language, price is the mechanism that determines who has the right to live and who has to get out of life. For example, with the current high cost of health services and medicines, only people with money can afford to pay for health care in hospitals and health clinics. While the less fortunate or the mediocre, when they are in dire need of treatment, they should make the most of their efforts to earn enough money including by indebtedness so that they can pay for medical services and the price of medicines exorbitant. When they are unable to earn the necessary amount of money, they are forced to let themselves or their ill relatives without treatment. Another example is the policy of elimination of college subsidies by the government which resulted in the cost of education, especially the cost of education in the favorite college increased sharply so it is very difficult to reach by middle to lower class society. This policy ultimately determines who are the Indonesian youths who are eligible to continue their education to universities, even some universities provide a special place for the rich through a "special path." The two examples above illustrate that price is the power that filters out people who are entitled to health and education services. Price also determines who the consumer (community members) can get various basic needs such as food, fuel, electricity, water, and shelter, as well as to get various secondary and tertiary needs such as telephone, computer, car, so the price determines which community can meet the needs of his life naturally, excessively, or minimally. With the filtering of community groups so that some of them fulfill their minimal needs, the Capitalist Economic System has determined that they are not worthy to live.

\section{j Price Structure as Econmic Capitalist Distribution Method}

Price structure as a meeting point between producer supply and consumer demand is the method of economic distribution in the Capitalist Economic System. The meeting between the prevailing price level in the market and the consumer's decision to buy goods and services is a means of filtering where the goods sell and do not sell. Both conditions have their own consequences. The first consequence of goods sold in the market is the possibility of profit obtained by the manufacturer. At the time of this 
profitable manufacturer he will decide whether the level of production (supply) is fixed or raised.

The second consequence of unsold goods on the market is the possibility of losses experienced by producers. Where at that time, when the producer can still bear the losses he experienced then he keeps doing production though by lowering the level of production. Conversely, when the producer is no longer able to bear losses, then for him must stop production or in other words close his business.

The combination of two consequences produces or alters the previous production rate. As for the meaning of production rate concerns three things, namely what goods are produced? How many are produced? And for whom the goods are produced?

For producers, goods produced are goods and services that generate profits, ie goods that sell in the market. While the level of production is adjusted to the level of consumer demand based on the production capabilities of the manufacturer.

The purpose of "for whom the goods are produced"?? are those goods and services produced to meet the "consumer demand".

The scope of "consumer demand" not the overall consumer or society at large, but a group of consumers or some people who demand the goods and services offered by the producer. Where the ability of consumers to demand depends on the strength of their purchasing power. So it is only for the consumer that the goods and services produced are destined, not for the poor or the poor. Two meeting points between "consumer demand" which has the ability to offer producers with the ability to produce economic equilibrium. As the previous explanation, that price determines who can enter into the production area and anyone who can consume consumer goods and services. This is what is meant by price as the method of economic distribution.

Distribution for producers is when the price (production cost) determines to stop production or remain capable of producing. For producers who remain capable of production, they must evaluate and rearrange what goods are produced (including quality issues), how much to produce, and which consumer groups are targeted. The distribution for the consumer is when the price requires it to calculate its ability to buy goods and services. Price makes a group of consumers who are able to meet all the needs and desires. Price makes a group of consumers who lack the ability to not fully consume the goods and services needed. Price also makes consumers who are not at all able to bite the finger because it cannot consume the goods it needs.

\section{$k \quad$ Price as Production Drivers}

Production activities undertaken by the producers are highly dependent on the ability of producers to bear the cost of production, where one of the production costs that must be borne by the producer is the cost of wages. On this basis, then there are two parties who synergize to produce, namely entrepreneurs as producers and workers as people who provide services to entrepreneurs in conducting production activities.

For entrepreneurs, raising capital to perform production is an attempt to gain profit. As for workers (laborers, employees, and managers) willingness to be under the entrepreneur by doing production activities is an attempt to get wages. 
Profits earned by employers and wages earned workers essence is the price. The profit for the entrepreneur is the price he gets from the consumer, while the wage for the worker is the price that the employer must pay. Thus price is the driving force of production. From the above explanation, it can be deduced that the productive or productive activities of man in the view of Capitalism is a human sacrifice driven by material incentives.

\section{Conclusion}

Theoretical framework in conventional economics, the birth of the science of economic behavior is based on a limited amount of resources with unlimited needs. The phenomenon of such limitation gives birth to a condition called scarcity. The emergence of scarcity encourages a variety of problems in choosing (problem of choices) that must be completed to achieve a goal called welfare.

Consumer Behavior Theory studies how humans choose between the various options they face by utilizing the resources it has. The theory of rational consumer behavior in the conventional economic paradigm is based on the basic principles of utilitarianism. Initiated by Bentham who says that in general no one can know what is good for his own good except the person himself. Thus restrictions on individual freedom, either by other individuals or by the authorities, are evil and there must be a compelling reason for doing so.

Profits earned by employers and wages earned workers essence is the price. The profit for the entrepreneur is the price he gets from the consumer, while the wage for the worker is the price that the employer must pay. Thus price is the driving force of production. From the above explanation, it can be deduced that the productive or productive activities of man in the view of Capitalism is a human sacrifice driven by material incentives.

\section{Aknowledgement}

Thank you to the Chairman of STIE AAS Surakarta and especially to the editorial board of Journal IJEBAR STIE AAS Surakarta which has given opportunity, so my writing can be published.

\section{Reference}

Compton, N. Eric. 1991. Principle of Banking (terjemahan Alexander Oey. Jakarta: Akademia Pressindo.

Kahf, M., 1995, Ekonomi Islam, PustakaPelajar, Yogyakarta

Karim, A. Ir. , 2007. Ekonomi Mikro Islam, edisi ketiga, Rajawali Pers, Jakarta

Marton, Saad, Said, (2004), Ekonomi Islam Ditengah Krisis Ekonomi Global, Zikrul Hakim, Jakarta

Metwally, (1995), Teori dan model ekonomi islam. PT Bangkit Daya Insana, Jakarta

Nasution, M.E., Huda, N., dkk (2006). Pengenalan Ekslusif Ilmuekonomi Islam, Kencana Prenada Group, Jakarta

P3EI, 2008, Ekonomi Islam, Rajawali Pers, Jakarta

Rahardja, P. dan Mandala, M., 2004, Teori Ekonomi Mikro: Suatu Pengantar, edisi ketiga, Lembaga Penerbit FE UI, Jakarta. 
International Journal of Economics, Business and Accounting Research (IJEBAR)

Peer Reviewed - International Journal

Vol-2, Issue-2, 2018 (IJEBAR)

ISSN: 2614-1280, http://www.jurnal.stie-aas/ijebar

Sukirno, S., 2009, Mikro Ekonomi: Teori Pengantar, edisi ketiga, Rajawali Pers, Jakarta

Yusuf, Q., 2002, Halal dan Haram dalam Islam,BinaIlmu,Surabayahttp://ekonom ikonvensionaldanekonomiislam.blogsp ot.com/2011/10/pengertiankonsumsi.html, diambil tanggal 11 Maret 2013. 